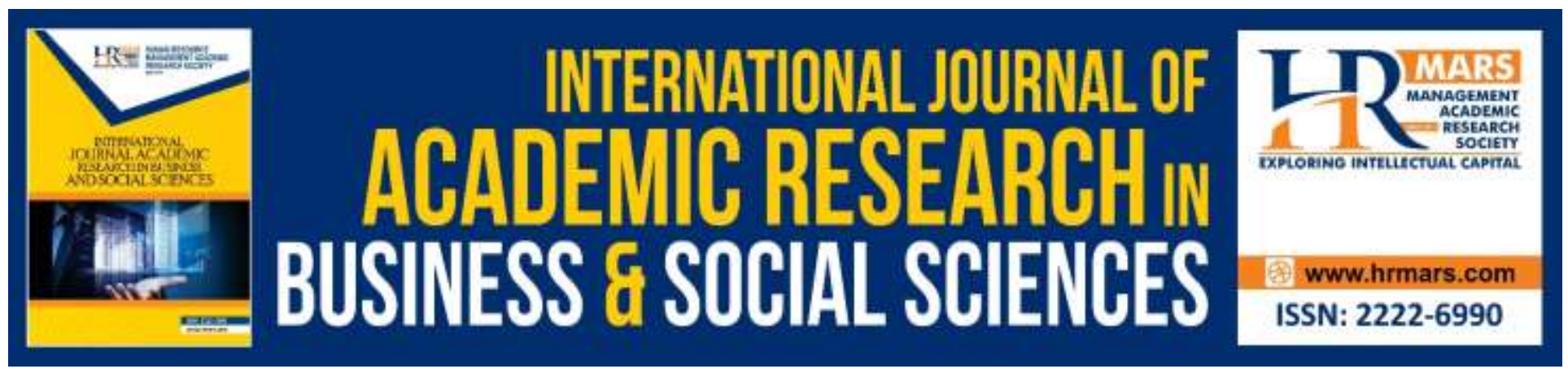

\title{
Distance to default of Malaysian Corporate Sukuk Issuers: A Differential Study for Different Economic Sectors
}

Awais Ur Rehman, Muhammad Abdullah bin Zaidel, Mohamad bin Jais, Arslan Haneef Malik

To Link this Article: http://dx.doi.org/10.6007/IJARBSS/v10-i5/7227

DOI:10.6007/IJARBSS/v10-i5/7227

Received: 06 March 2020, Revised: 18 April 2020, Accepted: 25 April 2020

Published Online: 19 May 2020

In-Text Citation: (Rehman et al., 2020)

To Cite this Article: Rehman, A. U., Zaidel, M. A. bin, Jais, M. bin, \& Malik, A. H. (2020). Distance to default of Malaysian Corporate Sukuk Issuers: A Differential Study for Different Economic Sectors. International Journal of Academic Research in Business and Social Sciences, 10(5), 546-556.

Copyright: (C) 2020 The Author(s)

Published by Human Resource Management Academic Research Society (www.hrmars.com)

This article is published under the Creative Commons Attribution (CC BY 4.0) license. Anyone may reproduce, distribute, translate and create derivative works of this article (for both commercial and non-commercial purposes), subject to full attribution to the original publication and authors. The full terms of this license may be seen

at: http://creativecommons.org/licences/by/4.0/legalcode

Vol. 10, No. 5, 2020, Pg. 546 - 556

http://hrmars.com/index.php/pages/detail/IJARBSS

JOURNAL HOMEPAGE

Full Terms \& Conditions of access and use can be found at http://hrmars.com/index.php/pages/detail/publication-ethics 


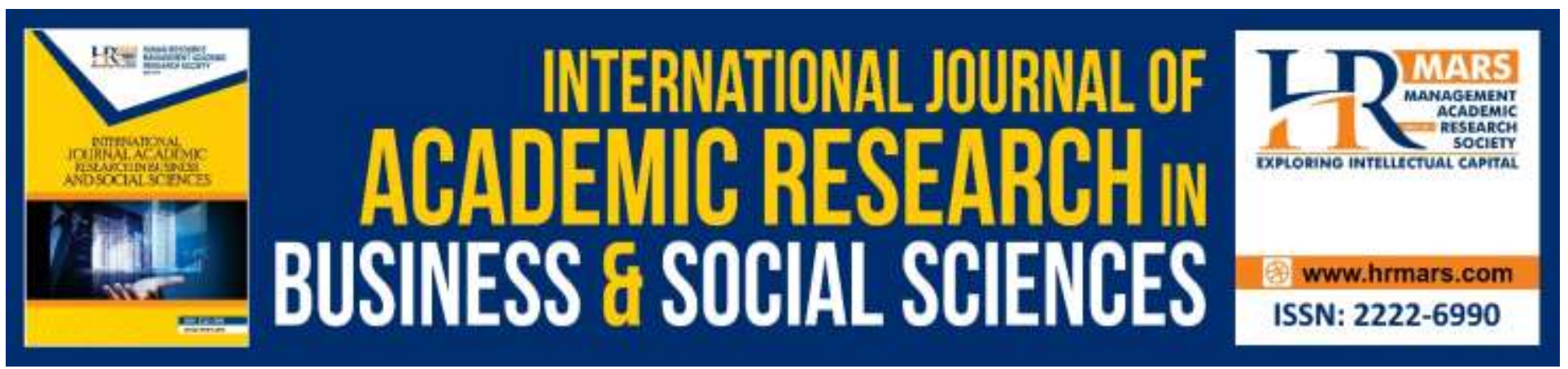

\title{
Distance to default of Malaysian Corporate Sukuk Issuers: A Differential Study for Different Economic Sectors
}

\section{Awais Ur Rehman, Muhammad Abdullah bin Zaidel, Mohamad bin Jais, Arslan Haneef Malik}

Faculty of Economics \& Business, University Malaysia Sarawak.

Email: ever.awais@gmail.com

\begin{abstract}
The Malaysia enjoys the monetary and non-monetary benefits for being the sukuk hub for globe. Malaysian market has already suffered much from defaults. To save them from future defaults the periodic update must be taken for the closeness of defaults. This study calculated distance to default (DD) for 231 observations for the time period of 2011-2017 in the post-crisis era. It was noted that the sukuk issuers are although diverse in their credit profiles, on the aggregate most of them are having strong level of assets to absorb their liability pay-offs. The DD values were at highest level for logistics, industrial goods, manufacturing, real estate and construction and lowest in energy sector. Directions for future research were also discussed in concluding part of this paper.
\end{abstract}

\section{Introduction}

It is reported by the esteemed institute of IMF that Islamic finance has emerged as a strong reality and the part of the financial markets, especially after it has shown a noteworthy resilience against the crisis. Although its market share is not a big chunk, yet it has successfully penetrated in the markets around the globe. The report adds that the rapid growth in Islamic finance was made possible due to the instruments of sukuk. Sukuk can be outreached across the geographic boundaries and has won the investors' confidence, therefore the industry needs to make sukuk more prosperous. Sukuk has rightfully added economic efficiency and liquidity in the market. It is also import element of Islamic financial industry due to its size. $95 \%$ of assets in Islamic financial industry are held by Islamic banks and sukuk issuers (IMF, 2015). Its size is growing even more with an annual rate of $27.8 \%$ (Mohammed, 2015).

The growth trajectory of sukuk is merely a single side of the story. Among the sukuk issuers all is not going in a perfect and promising way. Till the year 2015, the sukuk issuances kept their growth steady and positive, with the issuances in 2013 at record high. But after the 2015 the sukuk market has entered in the "consolidation phase". The market under this phase is face different kind of challenges that are pressing the issuances negatively (IIFM, 2016, p. 3). One of these factors, the sukuk defaults in past have given a negative impact on the market. 
Only in the Malaysian market 26 cases of sukuk defaults have hit the market by 2000 to 2013, while the 2009 saw the highest cases of sukuk defaults. By the 2009 the market had to bear a series of default. The researchers of Islamic finance have termed this year as the year of default that had long lasting consequences on sukuk market (Shahida, Hafizuddin Syah, Daud, \& Hafizi, 2014; Kamarudin, Kamaluddin, Manan, \& Ghani, 2014). The financial crisis was hitting the market that triggered the defaults even worst. Researchers are worried that the aftermaths of financial crisis are not over yet, therefore the defaults can be a concern for the market even today (Majid, Shahimi, \& Abdullah, 2010).

When the defaults erupted the market was largely ignorant of it. The academia, the legal personnel and the rating agencies, were all not expecting those much defaults to be occurred. Only a few cases were known to the market players. But the defaults are not arbitrary in nature. The disturbance in the receivables can create a liquidity issue to honor the payables. This interconnectivity of the market makes the defaults contagious. It caused a sequence of sukuk defaults with 21 cases occurred in 20 months only. Khinfer (2010) recounts that it was lamenting that the researchers were ignorant of it. He describes that if market has not turned blind and would have forecasted the defaults, the precautionary measures could have brought up aforehand and it may have lessened the losses. It was estimated that only in the Malaysia, USD 2.243 billion was the amount of loss that had to be borne by industry due to this ignorance from sukuk clones to defaults (Kamarudin, Kamaluddin, Manan, \& Ghani, 2014). The defaults are not easier to be tackled once they have erupted due to their contagious nature. Buckling up the belts before entering a rocky road is better in this case. Hence, it is necessary to timely and periodically update the market on defaults so that the precautions can be implemented timely and aforehand (Khalid, 2007; Saad, Haniff, \& Ali, 2016).

Hence this study aims to calculate the DD measures for sukuk issuers at the aggregate level and also for different economic sectors separately. Next section explains the discussion relating to DD afterwards the methodology section describes the discussion about data collection. After these the study presents its final results and draws a conclusion thereof. A number of future directions were also discussed for more studies on sukuk.

\section{Distance to Default as the Measure of Credit Risk}

Merton model is used extensively to measure the firms' proximity to default by the researchers and the practitioners. This fame of Merton model is up in the trend since its inception about a half of century ago (Afika, Aradb, \& Galil, 2016; Kim, Batten, \& Ryu, 2020). This model uses the market data and the accounting data as well. It is based upon the theory of option pricing model. Stockholders have residual claim on the business assets after the business liabilities have been paid off. Therefore, the stockholders are considered as the buyers of put option. They have an option to buy the business asset in lieu for the payment of liabilities as a strike price.

Model furthers its calculations based on some simple economic assumptions. The business asset has a variable value like a Brownian motion. It is not static and carries a variance. Secondly the firm has the liability of the firm can be imagined in the form of single of zero-coupon bond. This bond has a maturity term of T time period. Hence, the defaults can occur on at the elapse of time T not before it. Following to these assumptions the DD calculations can be shown by firstly quantifying the market value of the equity can be evaluated then by the following formula

$M V=A N\left(d_{1}\right)-e^{-R_{f}^{\top}} \operatorname{MTL} N\left(d_{2}\right)$

Where the variables presented in the equation are 
MV: market value of equity

A: firm value

$\mathrm{R}_{\mathrm{f}:}$ Risk free rate

MTL: market value of total liabilities

Pertinent to notes that all the values are taken from the market data except the variables of distribution. This variable can be calculated as

$\mathrm{d}_{1}=\left(\ln (\mathrm{A} / \mathrm{MTL})+\mathrm{Rf}+0.5 \sigma_{\mathrm{A}}^{2}\right) / \sigma_{\mathrm{A}} T$

While

$\sigma_{A}{ }^{2}$ : variance of the firm value

T: Time to maturity

The value of $d 2$ can be quantified by the equation

$\mathrm{d}_{2}=\mathrm{d}_{1}-\sigma_{\mathrm{A} v} \mathrm{~T}$

Moreover, the next equation is used to calculate $\sigma_{\mathrm{A}}$

$\sigma_{\mathrm{A}}=(\mathrm{A} / \mathrm{MV}) \mathrm{N}\left(\mathrm{d}_{1}\right) / \sigma_{\mathrm{E}}$

$\sigma_{E}$ displays the equity-volatility.

Many attempts to improve were made subsequently after the formulation of this model. Baharath and Shumway (2008) also made a similar strife to make the calculations easier and comprehendible. They replaced the sophist nonlinear quantifications with linear and easier ones. Their model was still arched over the option pricing theory, but it gave an easy in the calculations since all the data relating to their new variables are readily and publicly available. They uprooted all the unobservable quantities in the equations of DD. Their approach is termed as naïve model of DD. According to naïve model the volatilities can be calculated as

$\sigma_{\text {A. Naîve }}=\mathrm{MV} / \mathrm{MTA} \sigma_{\mathrm{E}}+\mathrm{TL} / \mathrm{MTA} \sigma_{\mathrm{D}}$

It is pertinent to note that the TL represents the total liabilities. These liabilities are taken at the book value rather than the market value. It gives an ease to trace this data from financial statements of the firms under discussion. Moreover, $\sigma_{D}$ is the notation for debt volatility and can be processed as $\sigma_{D}$ Naive $=0.05+0.25 \sigma_{E}$

Equity volatility $\left(\sigma_{\mathrm{E}}\right)$ is the standard deviation of total equity. By convention $25 \%$ of the equity volatility is taken and it is increased with 0.05 for term-structure volatility. These conventions are given by Baharath \& Shumway (2008) for the calculations of naïve values of DD. While after the calculations of volatilities, the DD can be calculated with following equation

$$
D D=\frac{\ln \left(\frac{\mathrm{MTA}}{\mathrm{TL}}\right)+\mathrm{T}\left(\mathrm{E}_{1 \mathrm{y}}-0.5 \sigma_{\mathrm{A}_{\text {Naive }}}^{2}\right)}{\sigma_{\mathrm{A}_{\text {Naive }}}^{2} \sqrt{\mathrm{T}}}
$$

$\mathrm{E}_{1 \mathrm{y}}$ represents the earnings of past year $\sigma_{\mathrm{A}_{\mathrm{Naive}}}^{2}$ represents the asset volatility and measured as the standard deviation of asset values. $T$ is the time period usually taken as one year as the convention. These conventions are used by the researchers are the well-known practitioners like KMV (Milne, 2014).

Here arises the equation that whether the results of DD are valid to not. Generally, the results are termed valid once they are cross verified and matched with an accepted reality. DD presents the distances in stand errors the firm is standing at from being indulged into the defaults. In the case of closeness to default, the DD must be shortened during the period of economic crisis as a valid 
measure for default risk. It was noted by a previous study by the empirical results from a large sample that the DD was showing a signal of risk in 2008. Although it did not show the signals for defaults in 2007 during the financial crisis. The DD can show a superior and timely results due to its market based inputs of calculations and free of "regulatory arbitrage" (Milne, 2014, p. 34).

Another pertinent question can be that whether the DD calculations are superior to other similar models. A study took a large data set to quantify the $Z$ and $O$ scores besides the DD as the proxy to predict the defaults. $Z$ and $O$ scores were calculated both by the basic and updated models. The results were compared based on out and in the sample technique. Findings showed that DD is more efficient to calculate default risk probability, therefore the study suggested that researchers to conduct their studies on default risk with DD model (Hillegeist, Keating, Cram, \& Lundstedt, 2004). The researchers of credit risk after discovering DD can be better then carried their investigations to the next level. They tried to answer the question that DD has different models and calibrations for getting the numeric on credit risk, so what model can be better one? Based upon the empirical findings, it was suggested that the naïve model of DD is more efficient being easier to quantify and superior in it results (Afika, Aradb, \& Galil, 2016; Agarwal \& Taffler, 2008; Bharath \& Shumway, 2008). Basing on this discussion it can be conclude that DD is an efficient model to analyze the credit risk.

\section{Methodology}

Aim of the study was to analyze the default closeness of corporate sukuk issuers at Malaysia. Therefore, the population for the study is the Malaysian corporates those have issued the sukuk. The data about sukuk issuers was collected from Bursa Malaysia stock exchange. To make a sample out of the population, the issuers were then filtered with the following attributes

1. The study selected the time period of 2011-2017. The study is aimed to analyze the sukuk defaults and the recent financial crisis had given a series of defaults, the year 2009 was the peak of defaults and it took one more year to vanish the negativities from the market. Therefore 2011 was selected as the start year for this study in the post crisis era.

2. The sukuks can be of different maturity structures. These structures can influence the financial status of the issuers. This financial status can be very different in pre and post eras of issuances and maturities. The issuance is the time of high cash inflow while the maturity impacts in an opposite way. To make the data homogenous and free from these biases and differences, the sukuk issuers were taken only in their active phase. The maturity of the sukuk issuers must be similar. They must not be matured yet by the end of 2017. In simple word the sukuks under discussion must be under trading for the tenure of the analysis.

3. The issuer must be registered as a public company for the accessibility of accounting and market data. For DD calculations the market share price is essential. The public companies have their active trading of shares and the market data is available from the trade floors, therefore, only public companies were taken in the sample.

4. The sukuk issuing corporate must be a non-financial company. The financial and non-financial companies have huge differences in their asset liability and capital structures. Their default analysis should be catered differently.

5. The corporates issued sukuks more than one time constitute a single cross section in this study. The single issuance or repetitions are same for this study. In other words, for a corporate to be a sukuk issuer it should have issued sukuk at least once. 
INTERNATIONAL JOURNAL OF ACADEMIC RESEARCH IN BUSINESS AND SOCIAL SCIENCES Vol. 10, No. 5, May, 2020, E-ISSN: 2222-6990 @ 2020 HRMARS

The sukuks at Malaysia with a maturity longer than 2017, there was 142 such cases. After the filtrations were applied it gave 33 issuers. A data of seven years from 2011-2017 gave the total observations of 231.

For the calculation of default risk, the DD measures were used. It has already been explained in the previous parts of the study. The sukuk issuers were further dived into the economic sectors for analyzing the default risk prevailing among different sectors. This division was adopted form the Bank Negara Malaysia. The Bank Nagara Malaysia is the central banks of Malaysia and has divided the sukuk issuers into sub economic sectors depending upon their nature of business and operations. The study has divided its sample firms into sub-samples. This division into economic sectors or the sub-samples was taken from the classification of sukuk issuers given by Bank Nagara Malaysia. Diving the issuers on the basis of their nature of operations is vogue among the academic circles and the practitioners. The rating agencies also divide the credit ratings in different economic sectors. It assumed that the macroeconomic factors are constant among the sectors and impacting them equally. While the firm specific characteristics are different among the sectors. These characters are matching among different firms under a single sector but are different under different sectors.

To verify that whether the differences among the means of DD among different economic sectors are statistically significant Kruskal Wallis test was employed. Based on the five assumptions of this test it was noted that the distribution of DD variable is non-normal with a skewness at positive values of DD. Moreover, the groups are more than two and the distribution under each group is different in shape. Therefore, the mean rank test was employed instead of analyzing the medians under different groups.

Interpretation of distance of default among economic sectors

\begin{tabular}{|l|l|l|l|l|l|l|}
\hline Economic Sectors & Mean & SD & Minimum & Maximum & Range & Mean Rank \\
\hline Communication and logistics & 1.1121 & 0.8768 & -1.0021 & 2.4144 & 3.4165 & 142.61 \\
\hline Industrial goods & 0.7887 & 0.8950 & -1.8900 & 2.3600 & 4.2500 & 116.08 \\
\hline Manufacturing & 0.7993 & 0.8128 & -0.5773 & 1.7544 & 2.3317 & 125.57 \\
\hline Property and construction & 0.6288 & 0.7647 & -0.8702 & 2.3513 & 3.2215 & 104.55 \\
\hline Energy and water & 0.4235 & 0.6082 & -0.5412 & 1.8903 & 2.4315 & 89.32 \\
\hline Overall & 2.0620 & 4.7413 & -1.89 & 2.41 & 4.3000 & \\
\hline
\end{tabular}

As discussed earlier the study used naïve model to calculate DD values for different economic sectors. The DD values represent the gap between the liabilities and the assets of a firm. More is the gap better is the firm in shouldering its liabilities. Put it differently the bigger DD values represent the lower level of default risk. For interpreting DD, it must be noted that naïve model aggregates the calculations on the basis of levels of debts, assets and the earrings. It also incorporates the volatility in the assets and the earnings of the firms. Hence, the means scores and the stand deviation should be considered while interpreting the DD scores among different economic sectors.

Table 1 represent the means, standard error, maximum and the minimum of DD for each sector separately. It can be noted that the sector of communication and logistics have the biggest value of DD 1.1121. It can be said that among the Malaysian sukuk issuers, the firms of communication and logistic business have the lowest default risk as calculated by DD. This finding can be compared to those of Weicheng (2018). By case study approach, it was shown by Weicheng (2018) that the logistics and communication business are having the least level of credit risk. Moreover, the DD values have 
INTERNATIONAL JOURNAL OF ACADEMIC RESEARCH IN BUSINESS AND SOCIAL SCIENCES Vol. 10, No. 5, May, 2020, E-ISSN: 2222-6990 @ 2020 HRMARS

their link to the asset levels held by the firms. The logistic and communication companies usually have high value assets like worthy vessels and vehicles (Stasytytė \& Pilionienė, 2017). The higher asset value gives a downward effect to the credit risk. Other linkage of the credit risk is with the liquidity management. Among the Malaysian firms the communication and logistic companies have made themselves efficient to manage their cash cycles after the financial crisis (Weisheng, 2018). Stasytyte and Pilionienè (2017) have noted, by the survey method, that the higher management at the communication and logistic companies are deterministic to increase their asset worth and to manage the credit risk as the high priorities of their business goals. These factors can be conclusive to lower the credit risk and increase the DD values among these firms.

The firms dealing in industrial goods had a DD of 0.7887. It was the next highest DD after the firms among the sector of communication and logistics. It is important to note that the standard deviation is highest for this sector. The highest standard error of the value 0.8950 approximate 0.9 can be the reason of a high DD in this sector. It has been noted that renowned rating agencies like Moody are of the view that the volatility can be a decrease in the leverage. The firms confronted with more asset or earning volatilities are expected to receive less credits on easier terms. That gives them a lesser exposure of leverage and higher DD values (Crosbie \& Bohn, 2003). The high deviation in the mean DD can also be noted by the high range of 4.2500 . Range tells the difference between the maximum and the minimum mean value for each sector. The range in the sector of industrial goods was the highest.

The economic sector of manufacturing firms was noted to have a mediocre level of DD valuing 0.7993. This value of DD lies exactly at the middle of the estimates of mean scores for each economic sector. The nature of business for manufacturing firms is multidimensional. These firms must deal with all the steps involved in, ranging from the acquisition of raw materials to final production packaging and sale-supplies (Zott \& Amit, 2010). These tasks make their cash cycle complex and press them to take financing from multi-resources. The manufacturing firms usually have diversified portfolio for financing. Their liabilities arise from leasing commitments, trade bills discounted etc. The bonds and so on the sukuk issuances, are a moderate part of their loan portfolios. While on the other hand their assets are also multi-faced ranging from land, building, machinery and supplying vehicles (AvouyiDovi, Mireille, Jardet, Kendaoui, \& Moquet, 2009). This phenomenon gives them a mix levels of asset and liabilities and a mediocre place in DD. For manufacturing firms, the mediocre value of DD 0.7993, is comparable to a similar value of DD 0.7656 , found for Chinese manufacturing firms (Zhenpeng \& Jingjing, 2011).

The lowest level of DD was associated with the sectors of construction and energy. Construction business is usually having high amount of leverage. Their initial investment and the cash out flow is usually high. They invest huge amounts as capital expenditure and then receive cash inflows periodically (Zaidel, 2014). The implementation of taxes on the land and construction sector has also put a burden on these firms to seek for more leverage and debts (Bernama, 2014). The energy sector has a similar investment trend that they must make heavy cash outflow in the start of the projects and they also rely heavily on the account receivables. The firms with heavy portion of account receivables in their financials can be at higher level of the credit risk (Kim, Cho, \& Ryu, 2019). The energy projects can be even more costly than the construction ones. The energy sector receives incentives too (Liebe, Gewinner, \& Diekmann, 2018). These incentives encourage them to make their business more levered and geared up with debts to start their new projects. 
The discussion can be summed up to state that the credit risk and DD values are significantly different among sukuk issuers of different economic sectors. These differences were tested by Kruskal Wallis test. The test yielded an asymptotic significance of 0.000 . Means values and the mean ranks indicate that sukuk issuers can be distinguished on their economic sectors. Except the sector of industrial goods, all the sectors have the range much smaller than the range for overall issuers. It means the assumption that firms in a single sector are similar to each other, is held true. While the variability in the industrial goods can be referred to their connectivity to other sectors. Unlike other sectors whose clients can be individuals too, the sector of industrial good is dealing with other industries. The defaults are not discretionary. The payment and the liquidity are interconnected. Therefore, the payment issues in one firm can lead to liquidity issues in other firms (Nin \& Tomás, 2019). The firms coming under the sector of industry goods can make them varied in their credit risk due to their dealing with different firms with different credit status.

The mean results and the mean ranks reveal that among different economic sectors of sukuk issuers communication and logistics and industrial goods had lower default risk and bigger values of DD. At the mediocre level was the manufacturing sector and property and energy sectors had the smallest values of DD. These results are comparable to the early studies. The default percentages were noted at lowest level for logistics $(0.019 \%)$, industrial goods $(0.018 \%)$, manufacturing $(0.022 \%)$, real estate and construction $(0.031 \%)$ and highest in energy sector $(0.032 \%)$, among Spanish corporations (Nin \& Tomás, 2019).

Overall the mean value of DD was around 2.0620 with a minimum of -1.89 and a maximum of 2.41 . It states that the sukuk issuers are having wide gap in their maximum and minimum values of DD with a positively skewed range of DD. Being positively skewed refers to the strength of the issuers that most of the observation occur in the positive region of DD instead of negative region. While interpreting the negative values of DD, it must be noted that it does not indicate and bankruptcy. Although the firms with negative DD may be able to honor their liabilities yet the company is under high pressure of leverage. The loan values taken by the firms are much higher than their asset levels. Hence, it should be interpreted as a credit stress not a mandatory default. The standard deviation and the range were 4.7413 and 4.3 , respectively. Both variables indicate the dispersion in the observations and pertinent to note that both are higher than any sector. Hence, the overall the issuers are diverse in their determinants of their credit risk while they are similar in a single sector. This phenomenon reaffirms the segregation assumption of economic sectors.

\section{Conclusion}

Malaysia is the global sukuk hub and have witnessed the series of defaults in the recent past. After the crisis the competitive pressure a=has amassed on Malaysia. If she needs to keep it sobriety being the sukuk hub and the leader of the market, it must periodically update the default levels pertaining in the sukuk issuers. The timely checkup can ring the bells and alter the regulators and partitions to manage their risks aforehand. The Malaysian sukuk issuers were analyzed for their default levels. The DD technique was used for its easier and superior calculations. Data was taken from 2011 to 2017. Certain filters were applied to undo the biases in the data. These filters yielded 33 firms with 231 number of observations. The DD measures were taken for overall sukuk issuing corporates and subsequently for different economic sectors of these corporates. These sectors were adapted from the divisions of issues done by Bank Nagara Malaysia. This division is theoretically built upon the 
segregation assumption, that the firms are similar under one sector but are different among different sectors.

It was noted that overall sukuk issuers have positive and negative DD values. Positive values show a strong resilience against the defaults while the negative values indicate a credit stress. The data showed a positive skewness that indicate that most of the observations lie in the positive region of DD. It can be noted that the sukuk issuers are although diverse in their credit profiles, on the aggregate most of them are having strong level of assets to absorb their liability pay-offs.

The mean results and the mean ranks reveal that among different economic sectors of sukuk issuers communication and logistics and industrial goods had lower default risk and bigger values of DD. At the mediocre level was the manufacturing sector and property and energy sectors had the smallest values of DD. While communication and logistic business have the lowest default risk as calculated by DD. Weicheng (2018) has also shown the results in confirmatory that communication and logistics sector it at the lowest for credit risk at Malaysia. Weicheng (2018) has argued that high asset values and efficient cash liquidity management are the reasons for their better health in credits. Stasytyte and Pilioniene (2017) has noted that the higher management at these companies are effective to lower down the risk level since they are concerned to maintain a high of asset worth and to manage the credit risk. For the sectoral differences, the firms under industrial goods were showing the next big DD after communication and logistics. These firms were also showing the highest dispersion among all the sectors. Their high volatility has caused them to receive lesser leverages and be at the higher ranks of DD. Since they are working for other industries, they are more connected to the other sectors than the consumer product firms. Their connectivity is the reason for their deviations in their DD values.

The manufacturing firms was noted to have a mediocre level of DD. They have a diversified and mix levels of asset and liabilities and therefore a mediocre place in DD. The lowest level of DD was associated with the sectors of construction and energy. They must make heavy cash outflow in the start of the projects and they also rely heavily on the account receivables. The firms with heavy portion of account receivables in their financials can be at higher level of the credit risk (Kim, Cho, \& Ryu, 2019). The energy projects can be even more costly than the construction ones. The energy sector receives incentives too (Liebe, Gewinner, \& Diekmann, 2018). These incentives encourage them to make their business more levered and geared up with debts to start their new projects.

This study explored the levels of default risk among sukuk issuers. The future study can be conducted to use different economic theories and more complex models by causal links. The study used DD as the measure for credit risk. Different measures can be calculated and compared by in the sample and out the sample technique for inter-comparison. The study used non-financial firms, while the financial firms account for nearly the half of issuers. A separate study can be conducted for financial firms only. The sample can be differentiated on the basis of their sukuk structures as well.

\section{References}

Afika, Z., Aradb, O., \& Galil, K. (2016). Using Merton model for default prediction: An empirical assessment of selected alternatives. Journal of Empirical Finance, 35(1), 43-67.

Agarwal, V., \& Taffler, R. (2008). Does Financial Distress Risk Drive the Momentum Anomaly? Financial Management, 37(3), 461-484. 
INTERNATIONAL JOURNAL OF ACADEMIC RESEARCH IN BUSINESS AND SOCIAL SCIENCES

Vol. 10, No. 5, May, 2020, E-ISSN: 2222-6990 @ 2020 HRMARS

Avouyi-Dovi, S., Mireille, B., Jardet, C., Kendaoui, L., \& Moquet, J. (2009). Macro stress testing with a macroeconomic credit risk model: Application to the French manufacturing sector. Banque de France.

Bernama. (2014). GST: Minimal impact on renovation sector. New Straits Times.

Bharath, S. T., \& Shumway, T. (2008). Forecasting Default with the Merton Distance to Default Model. Review of Financial Studies, 21(3), 1339-1369.

Crosbie, P., \& Bohn, J. (2003). Modeling Default Risk: Modeling Methedology. Moody's KMV.

Hillegeist, S. A., Keating, E. K., Cram, D. P., \& Lundstedt, K. G. (2004). Assessing the Probability of Bankruptcy. Review of Accounting Studies, 9(1), 5-34.

IIFM. (2016). Sukuk Report A Comprehensive Study Of The Global Sukuk Market 5th Edition. Manama, Kingdom of Bahrain: IIFM.

IMF. (2015). Islamic Finance and the role of IMF. International Montary Fund. Retrieved January 1, 2017 from http://www.imf.org/external/themes/islamicfinance/

Kamarudin, M. F., Kamaluddin, N., Manan, S. K., \& Ghani, G. M. (2014). Defaulters profile in Malaysia Sukuk market . Procedia - Social and Behavioral Sciences 145 ( ), 145(2014), 277 - 285.

Khalid, A. M. (2007). Bond Market Developments in Emerging Markets: Prospects and Challenges for Pakistan. SBP Research Bulletin, 3(1), 43-62.

Kim, H., Batten, J. A., \& Ryu, D. (2020). Financial crisis, bank diversification, and financial stability: OECD countries. International Review of Economics \& Finance, 65(2020), 94-104.

Kim, H., Cho, H., \& Ryu, D. (2019). Default Risk Characteristics of Construction Surety Bonds. The Journal of Fixed Income, 29(1), 77-87.

Liebe, U., Gewinner, J., \& Diekmann, A. (2018). What is missing in research on non-monetary incentives in the household energy sector? Energy policy, 123(1), 180-183.

Majid, H. A., Shahimi, S., \& Abdullah, M. H. (2010). Sukuk defaults and its implication: a case study of Malaysian capital market. Proceedings of the eighth International Conference on Islamic Economics and Finance. Doha: Center for Islamic Economics and Finance, Qatar Faculty of Islamic Studies, Qatar Foundation.

Milne, A. (2014). Distance to default and the financial crisis. Journal of Financial Stability, 12(1), 2636.

Mohammed, N. (2015). Global Growth Trends in Sukuk. Retrieved January 2, 2017 from Islamic Finance: https://www.islamicfinance.com/2015/01/global-growth-trends-in-sukuk/\#_ftn2

Saad, N. M., Haniff, M. N., \& Ali, N. (2016). The Role of Institutional Investors in Mitigating the Default Risks of Sukuk and Conventional Bonds. Procedia Economics and Finance, 35(1), 339 - 348.

Shahida, S., Syah, H. B., Daud, M. B., \& Hafizi, A. (2014). Predicting Probability of Defaults: The Case of Malaysian Sukuk Market. Persidangan Kebangsaan Ekonomi Malaysia ke-9 (PERKEM ke-9), (pp. 357 - 365). Kuala Terengganu,Terengganu.

Stasytytè, V., \& Pilionienè, R. (2017). Risk management model for transportation company. 9th International Scientific Conference on Business and Management 2016. Vilnius, LITHUANIA : Vilnius Gediminas Technical University.

Weisheng, C. (2018). Performance and risk: logistics and transportation company in Malaysia. Munich Personal RePEc Archive.

Zaidel, M. A. (2014). Distance to Default of Malaysian Corporate Bonds: Relationship Between Its Determinants and Corporate Governance. Kuching: Universiti Malaysia Sarawak. 
INTERNATIONAL JOURNAL OF ACADEMIC RESEARCH IN BUSINESS AND SOCIAL SCIENCES

Vol. 10, No. 5, May, 2020, E-ISSN: 2222-6990 @ 2020 HRMARS

Zott, C., \& Amit, R. (2010). Business model design: an activity system perspective. Long range planning, 43((2-3)), 216-226. 